\title{
Author Index Volume 35 (2014)
}

The issue number is given in front of the pagination

Abdul-Sattar, A.B., Predictors of functional outcome in patients with traumatic spinal cord injury after inpatient rehabilitation: In Saudi Arabia (2) 341347

Abraham, J.M., see Iyengar, Y.R. (2) 181-190

Agnani, O., see Sobry, V. (4) 851-861

Ahmaidi, S., see Leunkeu, A.N. (3) 597-606

Ahmaidi, S., see Leunkeu, A.N. (4) 657-663

Alekhina, M., see Manson, G.A. (4) 689-700

Allart, E., J. Paquereau, C. Rogeau, W. Daveluy, O. Kozlowski and M. Rousseaux, Construction and pilot assessment of the Lower Limb Function Assessment Scale (4) 729-739

Allart, E., see Rousseaux, M. (1) 25-30

Ambrose, A., see Lu, W. (2) 245-251

Amichai, T. and M. Katz-Leurer, Heart rate variability in children with cerebral palsy: Review of the literature and meta-analysis (1) 113-122

Amodeo, M.T., see Zimmermann, N. (1) 159-170

Anasetti, F., see Nardo, A. (4) 779-788

Ansari, N.N., see Raji, P. (3) 543-552

Ansley, B., see Glegg, S.M.N. (3) 563-577

Appel, C., L. Perry and F. Jones, Shoulder strapping for stroke-related upper limb dysfunction and shoulder impairments: Systematic review (2) 191204

Arango, J.A., see Morlett-Paredes, A. (4) 841-849

Arango-Lasprilla, J.C., see Morlett-Paredes, A. (4) 841849

Ashman, T., see Lee, Y.S.C. (1) 57-65

Ashman, T., see Lu, W. (2) 245-251

Auff, E., see Pusswald, G. (3) 519-527

Aurora, R.N., see Lu, W. (2) 245-251

A-Young, S., see Seong-Youl, C. (4) 771-778

Bach, L.J., Long term rehabilitation management and outcome of anti-NMDA receptor encephalitis: Case reports (4) 863-875

Badin, P., see Sobry, V. (4) 851-861

Barker, R.N., see Hayward, K.S. (1) 17-23
Barr, C.J., see McLoughlin, J.V. (3) 503-508

Beibei, L., see Caizhong, X. (4) 835-840

Bell, K., see Lequerica, A. (3) 485-492

Bennet, N., see Munivenkatappa, A. (3) 481-484

Bensmail, D., see Boudarham, J. (3) 369-379

Bernabeu Guitart, M., see Castaño Monsalve, B. (1) 67-76

Berryman, A., see Regier, A.D. (3) 467-473

Bertè, F., see De Luca, R. (4) 711-717

Bertolucci, F., see Chisari, C. (3) 509-518

Bhattacharjee, A., see Manson, G.A. (4) 689-700

Blanton, S., see Sawaki, L. (3) 415-426

Blasi, J., see Corral, L. (4) 763-769

Bode, M., see Morberg, B.M. (2) 291-298

Boudarham, J., D. Pradon, N. Roche, D. Bensmail and R. Zory, Effects of a dynamic-ankle-foot orthosis (Liberté ${ }^{\circledR}$ ) on kinematics and electromyographic activity during gait in hemiplegic patients with spastic foot equinus (3) 369-379

Boyaci, A., A. Tutoglu, N. Boyaci, I. Koca, M. Calik, A. Sakalar and N. Kilicaslan, Changes in spastic muscle stiffness after botulinum toxin A injections as part of rehabilitation therapy in patients with spastic cerebral palsy (1) 123-129

Boyaci, N., see Boyaci, A. (1) 123-129

Bramanti, P., see De Luca, R. (4) 711-717

Brauer, S.G., see Hayward, K.S. (1) 17-23

Brouwers, J., see Wood, R.M. (2) 171-179

Brum, C., see Glegg, S.M.N. (3) 563-577

Bushnick, T., see Lequerica, A. (3) 485-492

Butler, A.J., see Sawaki, L. (3) 415-426

Caizhong, X., S. Chunlei, L. Beibei, D. Zhiqing, D. Qinneng and W. Tong, The application of somatosensory evoked potentials in spinal cord injury rehabilitation (4) 835-840

Calabrò, R.S., see De Luca, R. (4) 711-717

Calik, M., see Boyaci, A. (1) 123-129

Campisi, J., see Lannin, N.A. (4) 635-641

Campos, T.F., see Silveira Fernandes, A.B.G. (1) 39-45 
Cannas, A., see Cugusi, L. (4) 789-794

Cano-de-la-Cuerda, R., L. Vela-Desojo, J.C. Miangolarra-Page and Y. Macías-Macías, Isokinetic dynamometry as a technologic assessment tool for trunk rigidity in Parkinson's disease patients (3) 493-501

Cantor, J., see Lequerica, A. (3) 485-492

Cantor, J., see Lu, W. (2) 245-251

Castaño Monsalve, B., S. Laxe, M. Bernabeu Guitart, A.B. Vilarrasa and J.I. Quemada, Behavioral scales used in severe and moderate traumatic brain injury (1) 67-76

Cernaianu, S., see Sobry, V. (4) 851-861

Cha, Y., Y. Kim, S. Hwang and Y. Chung, Intensive gait training with rhythmic auditory stimulation in individuals with chronic hemiparetic stroke: A pilot randomized controlled study (4) 681-688

Chan, R.-C., see Yeh, S.-C. (3) 435-449

Chen, S., see Yeh, S.-C. (3) 435-449

Chiaravalloti, N., see Goverover, Y. (2) 315-323

Chiaravalloti, N., see Lequerica, A. (3) 485-492

Chisari, C., M. Venturi, F. Bertolucci, C. Fanciullacci and B. Rossi, Benefits of an intensive task-oriented circuit training in Multiple Sclerosis patients with mild disability (3) 509-518

Chisari, C., see Tramonti, F. (1) 1-7

Chitambira, B., Does use of the optokinetic chart stimulation based OKCSIB protocol improve recovery of upper and lower limb movements, function and quality of life at 3 year follow up in dense strokes? A retrospective case control series (3) 451-458

Chong, H.J., S.J. Han, Y.J. Kim, H.Y. Park and S.J. Kim, Relationship between output from MIDIkeyboard playing and hand function assessments on affected hand after stroke (4) 673-680

Chung, Y., see Cha, Y. (4) 681-688

Chunlei, S., see Caizhong, X. (4) 835-840

Ciancio, M.R., see Pappalardo, A. (2) 215-220

Clark, K., see Finch, E. (1) 9-16

Conde, L., see Corral, L. (4) 763-769

Corral, L., L. Conde, E. Guillamó, J. Blasi, M. Juncadella, C. Javierre, G. Viscor and J.L. Ventura, Circulating progenitor cells during exercise, muscle electro-stimulation and intermittent hypobaric hypoxia in patients with traumatic brain injury: A pilot study (4) 763-769

Crotty, M., see McLoughlin, J.V. (3) 503-508

Cugusi, L., P. Solla, F. Zedda, M. Loi, R. Serpe, A. Cannas, F. Marrosu and G. Mercuro, Effects of an adapted physical activity program on motor and non-motor functions and quality of life in patients with Parkinson's disease (4) 789-794
Czernicki, J., see Krukowska, J. (3) 427-434

Daveluy, W., see Allart, E. (4) 729-739

Daveluy, W., see Rousseaux, M. (1) 25-30

De Luca, R., R.S. Calabrò, S. Reitano, G. Digangi, F. Bertè, G. Sergi and P. Bramanti, Should individuals with chronic aphasia be treated with dedicated PCbased training? Considerations about a case study (4) 711-717

De Pace, C., see Stasolla, F. (2) 253-259

DeLuca, J., see Goverover, Y. (2) 315-323

Devi, B.I., see Munivenkatappa, A. (3) 481-484

Digangi, G., see De Luca, R. (4) 711-717

Dijkers, M., see Lequerica, A. (3) 485-492

Doig, E., see Kuipers, P. (3) 475-480

Doutrellot, P.-L., see Leunkeu, A.N. (3) 597-606

Doutrellot, P.-L., see Leunkeu, A.N. (4) 657-663

Drodge, O., see Ploughman, M. (1) 105-112

Du, H., see Wang, Z. (4) 825-834

Dysch, L., see Morris, L.L. (3) 627-631

Eidenberger, M. and S. Nowotny, Inspiratory muscle training in patients with Amyotrophic Lateral Sclerosis: A systematic review (3) 349-361

Elder, M., see Lannin, N.A. (4) 635-641

Engelhardt, J., see Tánczos, T. (1) 137-146

Falland, R., see Lohse-Busch, H. (2) 235-244

Fanciullacci, C., see Chisari, C. (3) 509-518

Fanciullacci, C., see Tramonti, F. (1) 1-7

Fatoye, F., see Karimi, M. (2) 325-340

Finch, E., J. Fleming, K. Clark and K.S. Hayward, Interdisciplinary rehabilitation outcomes following thrombolysis for acute ischaemic stroke: A case series (1) 9-16

Fini, M., see Paoloni, M. (3) 405-414

Finn, M. and S. McDonald, A single case study of computerised cognitive training for older persons with mild cognitive impairment (2) 261-270

Fish, J., see Hynes, S.M. (3) 553-562

Fleming, J., see Finch, E. (1) 9-16

Fleming, J., see Kuipers, P. (3) 475-480

Fonseca, R.P., see Zimmermann, N. (1) 159-170

Forogh, B., see Raji, P. (3) 543-552

Franceschini, M., see Paoloni, M. (3) 405-414

Fregni, F., see Jeon, S.Y. (2) 271-278

Fritz, S.L., see Middleton, A. (4) 741-754

Frost, C., see Kane, H. (1) 89-95

Gaber, T.A.-Z.K., W.W. Oo and H. Ringrose, Multiple Sclerosis/Chronic Fatigue Syndrome overlap: When two common disorders collide (3) 529-534 
Genova, H., see Goverover, Y. (2) 315-323

Gerber, D., see Regier, A.D. (3) 467-473

Giffin, N., see Morris, L.L. (3) 627-631

Giunti, G., see Tramonti, F. (1) 1-7

Glegg, S.M.N., L. Holsti, S. Stanton, S. Hanna, D. Velikonja, B. Ansley, D. Sartor and C. Brum, Using virtual reality in clinical practice: A multisite exploratory study (3) 563-577

Goberman, A.M., see Smith, L.K. (1) 77-88

González-Mora, J.L., see Plata Bello, J. (4) 665-671

Good, D.C., see Sawaki, L. (3) 415-426

Gordon, W., see Lu, W. (2) 245-251

Gore, G.B., see Jani, M.P. (4) 719-727

Goverover, Y., H. Genova, H. Griswold, N. Chiaravalloti and J. DeLuca, Metacognitive knowledge and online awareness in persons with multiple sclerosis (2) 315-323

Grams, L., see Kerling, A. (1) 97-104

Griffiths, J.D., see Wood, R.M. (2) 171-179

Griswold, H., see Goverover, Y. (2) 315-323

Guillamó, E., see Corral, L. (4) 763-769

Hackney, M.E., see McKee, K.E. (2) 279-289

Halpern, M.T., see Kane, H. (1) 89-95

Hammond, F., see Lequerica, A. (3) 485-492

Han, S.J., see Chong, H.J. (4) 673-680

Han, S.J., see Jeon, S.Y. (2) 271-278

Han, S.J., see Na, E.H. (3) 459-466

Hands, G.L., see Malloy, J.R. (4) 795-803

Hanna, S., see Glegg, S.M.N. (3) 563-577

Hansen, D., see Op 't Eijnde, B. (4) 805-811

Harris, C., see Ploughman, M. (1) 105-112

Harrist, C.J., see Ness, B.M. (1) 147-158

Hasson, S., see Raji, P. (3) 543-552

Hays, K., see Regier, A.D. (3) 467-473

Hayward, K.S., S.S. Kuys, R.N. Barker and S.G. Brauer, Can stroke survivors with severe upper arm disability achieve a clinically important change in arm function during inpatient rehabilitation? A multicentre, prospective, observational study (1) $17-23$

Hayward, K.S., see Finch, E. (1) 9-16

He, Y., see Wang, Z. (4) 825-834

Hebert, J.R., see Rudroff, T. (4) 813-823

Henry, K., see Lannin, N.A. (4) 635-641

Herter, T.M., see Middleton, A. (4) 741-754

Hiyamizu, M., H. Maeoka, A. Matsuo and S. Morioka, Effects of self-action observation on standing balance learning: A change of brain activity detected using functional near-infrared spectroscopy (3) 579-585

Hnyilicza, Z., see Tánczos, T. (1) 137-146
Hogan, S.H., see Ploughman, M. (1) 105-112

Holsti, L., see Glegg, S.M.N. (3) 563-577

Horstmann, H., see Kerling, A. (1) 97-104

$\mathrm{Hu}, \mathrm{X}$., see Jahanmiri-Nezhad, F. (2) 307-314

Hussain, S., State-of-the-art robotic gait rehabilitation orthoses: Design and control aspects (4) 701-709

Hwang, P.W., see Lee, D.R. (1) 131-136

Hwang, S., see Cha, Y. (4) 681-688

Hynes, S.M., J. Fish and T. Manly, Using video ratings to assess multitasking performance in a naturalistic paradigm (3) 553-562

Hyun You, S. (Joshua), see Shin, Y.K. (3) 587-596

Ikuno, K., see Nakamura, J. (1) 31-37

Iyengar, Y.R., K. Vijayakumar, J.M. Abraham, Z.K. Misri, B.V. Suresh and B. Unnikrishnan, Relationship between postural alignment in sitting by photogrammetry and seated postural control in post-stroke subjects (2) 181-190

Jae-Shin, L., see Seong-Youl, C. (4) 771-778

Jahanmiri-Nezhad, F., X. Hu, N.L. Suresh, W.Z. Rymer and P. Zhou, EMG-force relation in the first dorsal interosseous muscle of patients with amyotrophic lateral sclerosis (2) 307-314

Jakab, K., see Tánczos, T. (1) 137-146

Jani, M.P. and G.B. Gore, Occurrence of communication and swallowing problems in neurological disorders: Analysis of forty patients (4) 719-727

Javierre, C., see Corral, L. (4) 763-769

Jensen, J., see Morberg, B.M. (2) 291-298

Jeon, H.S., see Shin, Y.K. (3) 587-596

Jeon, S.Y., S.J. Han, J.H. Jeong and F. Fregni, Effect of exercise on balance in persons with mild cognitive impairment (2) 271-278

Jeong, J.H., see Jeon, S.Y. (2) 271-278

Johnson, S., see Kane, H. (1) 89-95

Jones, F., see Appel, C. (2) 191-204

Juncadella, M., see Corral, L. (4) 763-769

Kammersgaard, L.P., see Linnemann, M. (4) 755-761

Kanada, Y., see Koyama, S. (3) 363-368

Kane, H., M.T. Halpern, S. Teixeira-Poit, C. Frost, M. Keating, M. Olmsted and S. Johnson, Factors influencing interest in providing MS patient care among physiatry residents (1) 89-95

Kaneko, T., see Koyama, S. (3) 363-368

Kanno, T., see Koyama, S. (3) 363-368

Karimi, M., A.H.H. Omar and F. Fatoye, Spinal cord injury rehabilitation: Which way forward? (2) 325-340 
Karki, R., see Rudroff, T. (4) 813-823

Katz-Leurer, M., see Amichai, T. (1) 113-122

Keating, M., see Kane, H. (1) 89-95

Kendall, M., see Kuipers, P. (3) 475-480

Keresztes, L., see Tánczos, T. (1) 137-146

Kerling, A., K. Keweloh, U. Tegtbur, M. Kück, L. Grams, H. Horstmann and A. Windhagen, Physical capacity and quality of life in patients with multiple sclerosis (1) 97-104

Keweloh, K., see Kerling, A. (1) 97-104

Keytsman, C., see Op 't Eijnde, B. (4) 805-811

Kilicaslan, N., see Boyaci, A. (1) 123-129

Kim, D.A., see Lee, D.R. (1) 131-136

Kim, D.H., see Shin, Y.K. (3) 587-596

Kim, J., see Kim, Y. (3) 607-614

Kim, S.J., see Chong, H.J. (4) 673-680

Kim, Y., J. Kim, J.K. Shim, D.-W. Suh and B.C. Yoon, The hypoalgesic effect of remote tactile sensory modulation on the mechanical sensitivity of trigger points: A randomized controlled study (3) 607-614

Kim, Y., see Cha, Y. (4) 681-688

Kim, Y.H., see Lee, D.R. (1) 131-136

Kim, Y.J., see Chong, H.J. (4) 673-680

Kindred, J.H., see Rudroff, T. (4) 813-823

Kita, Y., see Nakamura, J. (1) 31-37

Kitamua, S., see Luchesi, K.F. (3) 535-542

Klivényi, P., see Tánczos, T. (1) 137-146

Koca, I., see Boyaci, A. (1) 123-129

Kolakowsky-Hayner, S.A., see Lequerica, A. (3) 485492

Kong, K.-H. and J. Lee, Temporal recovery of activities of daily living in the first year after ischemic stroke: A prospective study of patients admitted to a rehabilitation unit (2) 221-226

Koo, P.J., see Rudroff, T. (4) 813-823

Kou, D., see Wang, Z. (4) 825-834

Koyama, S., S. Tanabe, H. Warashina, T. Kaneko, H. Sakurai, Y. Kanada, J. Nagata and T. Kanno, NMES with rTMS for moderate to severe dysfunction after stroke (3) 363-368

Kozlowski, O., see Allart, E. (4) 729-739

Kozlowski, O., see Rousseaux, M. (1) 25-30

Krellman, J.W., see Lu, W. (2) 245-251

Krukowska, J., E. Świątek, M. Sienkiewicz and J. Czernicki, Influence of the surface electrostimulation controlled by muscle contraction on the bioelectric muscle activity and restoration of the hand function in cerebral stroke patients (3) 427-434

Kück, M., see Kerling, A. (1) 97-104
Kuipers, P., E. Doig, M. Kendall, B. Turner, M. Mitchell and J. Fleming, Hope: A further dimension for engaging family members of people with ABI (3) 475-480

Kuys, S.S., see Hayward, K.S. (1) 17-23

Langmore, S.E., see Malloy, J.R. (4) 795-803

Lannin, N.A., K. Laver, K. Henry, M. Turnbull, M. Elder, J. Campisi, J. Schmidt and E. Schneider, Effects of case management after brain injury: A systematic review (4) 635-641

Laver, K., see Lannin, N.A. (4) 635-641

Laxe, S., see Castaño Monsalve, B. (1) 67-76

Lee, D.R., see Shin, Y.K. (3) 587-596

Lee, D.R., Y.H. Kim, D.A. Kim, J.A. Lee, P.W. Hwang, M.J. Lee and S.H. You, Innovative strength training-induced neuroplasticity and increased muscle size and strength in children with spastic cerebral palsy: An experimenter-blind case study - three-month follow-up (1) 131-136

Lee, J., see Kong, K.-H. (2) 221-226

Lee, J.A., see Lee, D.R. (1) 131-136

Lee, J.J., see Shin, Y.K. (3) 587-596

Lee, M.J., see Lee, D.R. (1) 131-136

Lee, S.-H., see Yeh, S.-C. (3) 435-449

Lee, Y.S.C., T. Ashman, A. Shang and W. Suzuki, Brief report: Effects of exercise and self-affirmation intervention after traumatic brain injury (1) 57-65

Lehrner, J., see Pusswald, G. (3) 519-527

Lelard, T., see Leunkeu, A.N. (3) 597-606

Lelard, T., see Leunkeu, A.N. (4) 657-663

Leng, X., see Sawaki, L. (3) 415-426

Lequerica, A., N. Chiaravalloti, J. Cantor, M. Dijkers, J. Wright, S.A. Kolakowsky-Hayner, T. Bushnick, F. Hammond and K. Bell, The factor structure of the Pittsburgh Sleep Quality Index in persons with traumatic brain injury. A NIDRR TBI model systems module study (3) 485-492

Leunkeu, A.N., T. Lelard, R.J. Shephard, P.-L. Doutrellot and S. Ahmaidi, Reproducibility of gait cycle and plantar pressure distribution in children with spastic hemiplegic cerebral palsy (3) 597-606

Leunkeu, A.N., T. Lelard, R.J. Shephard, P.-L. Doutrellot and S. Ahmaidi, Gait cycle and plantar pressure distribution in children with cerebral palsy: Clinically useful outcome measures for a management and rehabilitation (4) 657-663

Li, Z., see Wang, Z. (4) 825-834

Liang, H., see You, G. (3) 381-389

Lima, R.C.M., S.M. Michaelsen, L.R. Nascimento, J.C. Polese, N.D. Pereira and L.F. Teixeira-Salmela, 
Addition of trunk restraint to home-based modified constraint-induced movement therapy does not bring additional benefits in chronic stroke individuals with mild and moderate upper limb impairments: A pilot randomized controlled trial (3) 391-404

Linnemann, M., M. Tibæk and L.P. Kammersgaard, Hydrocephalus during rehabilitation following severe TBI. Relation to recovery, outcome, and length of stay (4) 755-761

Liuzzo, D.M., see Middleton, A. (4) 741-754

Lohse-Busch, H., E. Marlinghaus, U. Reime and U. Möwis, Focused low-energy extracorporeal shock waves with distally symmetric polyneuropathy (DSPNP): A pilot study (2) 227-233

Lohse-Busch, H., U. Reime and R. Falland, Symptomatic treatment of unresponsive wakefulness syndrome with transcranially focused extracorporeal shock waves (2) 235-244

Loi, M., see Cugusi, L. (4) 789-794

Lord, S.R., see McLoughlin, J.V. (3) 503-508

Lorentzen, J., see Willerslev-Olsen, M. (4) 643-655

Lu, W., J. Cantor, R.N. Aurora, M. Nguyen, T. Ashman, L. Spielman, A. Ambrose, J.W. Krellman and W. Gordon, Variability of respiration and sleep during polysomnography in individuals with TBI (2) 245-251

Luchesi, K.F., S. Kitamua and L.F. Mourão, Amyotrophic Lateral Sclerosis survival analysis: Swallowing and non-oral feeding (3) 535-542

Macías-Macías, Y., see Cano-de-la-Cuerda, R. (3) 493501

Maeir, A., see Rotenberg-Shpigelman, S. (1) 47-56

Maeoka, H., see Hiyamizu, M. (3) 579-585

Malloy, J.R., J.C. Valentin, G.L. Hands, C.A. Stevens, S.E. Langmore, J.P. Noordzij and C.E. Stepp, Visuomotor control of neck surface electromyography in Parkinson's disease (4) 795 803

Mangone, M., see Paoloni, M. (3) 405-414

Manly, T., see Hynes, S.M. (3) 553-562

Manson, G.A., M. Alekhina, S.L. Srubiski, C.K. Williams, A. Bhattacharjee and L. Tremblay, Effects of robotic guidance on sensorimotor control: Planning vs. online control? (4) 689-700

Marlinghaus, E., see Lohse-Busch, H. (2) 227-233

Marrosu, F., see Cugusi, L. (4) 789-794

Matsuo, A., see Hiyamizu, M. (3) 579-585

McCarthy, J., see Ploughman, M. (1) 105-112
McDonald, S., see Finn, M. (2) 261-270

McKee, K.E. and M.E. Hackney, The Four Square Step Test in individuals with Parkinson's disease: Association with executive function and comparison with older adults (2) 279-289

McLoughlin, J.V., C.J. Barr, M. Crotty, D.L. Sturnieks and S.R. Lord, Six minutes of walking leads to reduced lower limb strength and increased postural sway in people with Multiple Sclerosis (3) 503-508

Mercuro, G., see Cugusi, L. (4) 789-794

Miangolarra-Page, J.C., see Cano-de-la-Cuerda, R. (3) 493-501

Michaelsen, S.M., see Lima, R.C.M. (3) 391-404

Middleton, A., S.L. Fritz, D.M. Liuzzo, R. NewmanNorlund and T.M. Herter, Using clinical and robotic assessment tools to examine the feasibility of pairing tDCS with upper extremity physical therapy in patients with stroke and TBI: A consideration-of-concept pilot study (4) 741-754

Mildner, C., see Pusswald, G. (3) 519-527

Misri, Z.K., see Iyengar, Y.R. (2) 181-190

Mitchell, M., see Kuipers, P. (3) 475-480

Modroño, C., see Plata Bello, J. (4) 665-671

Mohammad, Y.M., see Sawaki, L. (3) 415-426

Morberg, B.M., J. Jensen, M. Bode and L. Wermuth, The impact of high intensity physical training on motor and non-motor symptoms in patients with Parkinson's disease (PIP): A preliminary study (2) 291-298

Morioka, S., see Hiyamizu, M. (3) 579-585

Morlett-Paredes, A., P.B. Perrin, S.L. Olivera, H.L. Rogers, J.L. Perdomo, J.A. Arango and J.C. Arango-Lasprilla, With a little help from my friends: Social support and mental health in SCI caregivers from Neiva, Colombia (4) 841-849

Morris, L.L., L. Dysch, P.M. Salkovskis and N. Giffin, Reducing excess stiffness in Stiff Person Syndrome using CBT: A case study (3) 627-631

Mourão, L.F., see Luchesi, K.F. (3) 535-542

Möwis, U., see Lohse-Busch, H. (2) 227-233

Munivenkatappa, A., J. Rajeswaran, B.I. Devi, N. Bennet and N. Upadhyay, EEG Neurofeedback therapy: Can it attenuate brain changes in TBI? (3) 481-484

Na, E.H., S.J. Han and T.S. Yoon, Effect of active pulmonary rehabilitation on pulmonary function in patients with brain lesion (3) 459-466

Nagata, J., see Koyama, S. (3) 363-368 
Naghdi, S., see Raji, P. (3) 543-552

Nakamura, J., Y. Kita, T. Yuda, K. Ikuno, Y. Okada and K. Shomoto, Effects of galvanic vestibular stimulation combined with physical therapy on pusher behavior in stroke patients: A case series (1) $31-37$

Nardo, A., F. Anasetti, D. Servello and M. Porta, Quantitative gait analysis in patients with Parkinson treated with deep brain stimulation: The effects of a robotic gait training (4) 779-788

Nascimento, L.R., see Lima, R.C.M. (3) 391-404

Németh, D., see Tánczos, T. (1) 137-146

Ness, B.M., M.R. Rocke, C.J. Harrist and K.G. Vroman, College and combat trauma: An insider's perspective of the post-secondary education experience shared by service members managing neurobehavioral symptoms (1) 147-158

Netto, T.M., see Zimmermann, N. (1) 159-170

Newman-Norlund, R., see Middleton, A. (4) 741-754

Nguyen, M., see Lu, W. (2) 245-251

Nichols-Larsen, D.S., see Sawaki, L. (3) 415-426

Nielsen, J.B., see Willerslev-Olsen, M. (4) 643-655

Nolan, K.J., see Pilkar, R. (2) 299-305

Noordzij, J.P., see Malloy, J.R. (4) 795-803

Nowotny, S., see Eidenberger, M. (3) 349-361

Okada, Y., see Nakamura, J. (1) 31-37

Oliveira dos Passos, J., see Silveira Fernandes, A.B.G. (1) $39-45$

Olivera, S.L., see Morlett-Paredes, A. (4) 841-849

Olmsted, M., see Kane, H. (1) 89-95

Omar, A.H.H., see Karimi, M. (2) 325-340

Oo, W.W., see Gaber, T.A.-Z.K. (3) 529-534

Op 't Eijnde, B., C. Keytsman, I. Wens and D. Hansen, Whole-body cooling does not compromise muscle oxidative capacity in subjects with multiple sclerosis (4) 805-811

Paiva de Brito, D., see Silveira Fernandes, A.B.G. (1) 39-45

Paoloni, M., E. Tavernese, M. Fini, P. Sale, M. Franceschini, V. Santilli and M. Mangone, Segmental muscle vibration modifies muscle activation during reaching in chronic stroke: A pilot study (3) 405-414

Pappalardo, A., M.R. Ciancio and F. Patti, Is the basic trunk control recovery different between stroke patients with right and left hemiparesis? (2) 215 220

Paquereau, J., see Allart, E. (4) 729-739

Park, H.Y., see Chong, H.J. (4) 673-680

Patti, F., see Pappalardo, A. (2) 215-220
Perdomo, J.L., see Morlett-Paredes, A. (4) 841-849

Pereira, N.D., see Lima, R.C.M. (3) 391-404

Perrin, P.B., see Morlett-Paredes, A. (4) 841-849

Perry, L., see Appel, C. (2) 191-204

Pilkar, R., M. Yarossi and K.J. Nolan, EMG of the tibialis anterior demonstrates a training effect after utilization of a foot drop stimulator (2) 299-305

Plata Bello, J., C. Modroño and J.L. González-Mora, The role of mirror neurons in neurosurgical patients: A few general considerations and rehabilitation perspectives (4) 665-671

Ploughman, M., J. Shears, C. Harris, S.H. Hogan, O. Drodge, S. Squires and J. McCarthy, Effectiveness of a novel community exercise transition program for people with moderate to severe neurological disabilities (1) 105-112

Polese, J.C., see Lima, R.C.M. (3) 391-404

Porta, M., see Nardo, A. (4) 779-788

Powis, I., see Sorinola, I.O. (2) 205-213

Pradon, D., see Boudarham, J. (3) 369-379

Purdy, M., see Wallace, S.E. (3) 615-625

Pusswald, G., C. Mildner, K. Zebenholzer, E. Auff and J. Lehrner, A neuropsychological rehabilitation program for patients with Multiple Sclerosis based on the model of the ICF (3) 519-527

Qinneng, D., see Caizhong, X. (4) 835-840

Quemada, J.I., see Castaño Monsalve, B. (1) 67-76

Rajeswaran, J., see Munivenkatappa, A. (3) 481-484

Raji, P., N.N. Ansari, S. Naghdi, B. Forogh and S. Hasson, Relationship between Semmes-Weinstein Monofilaments perception Test and sensory nerve conduction studies in Carpal Tunnel Syndrome (3) 543-552

Regier, A.D., A. Berryman, K. Hays, C. Smith, K. Staniszewski and D. Gerber, Two approaches to manual wheelchair configuration and effects on function for individuals with acquired brain injury (3) $467-473$

Reime, U., see Lohse-Busch, H. (2) 227-233

Reime, U., see Lohse-Busch, H. (2) 235-244

Reitano, S., see De Luca, R. (4) 711-717

Ringrose, H., see Gaber, T.A.-Z.K. (3) 529-534

Rizzo, A., see Yeh, S.-C. (3) 435-449

Roche, N., see Boudarham, J. (3) 369-379

Rocke, M.R., see Ness, B.M. (1) 147-158

Rogeau, C., see Allart, E. (4) 729-739

Rogers, H.L., see Morlett-Paredes, A. (4) 841-849

Rosen-Shilo, L., see Rotenberg-Shpigelman, S. (1) 4756

Rossi, B., see Chisari, C. (3) 509-518 
Rossi, B., see Tramonti, F. (1) 1-7

Rotenberg-Shpigelman, S., L. Rosen-Shilo and A. Maeir, Online awareness of functional tasks following ABI: The effect of task experience and associations with underlying mechanisms (1) 47 56

Rousseaux, M., see Allart, E. (4) 729-739

Rousseaux, M., W. Daveluy, O. Kozlowski and E. Allart, Onabotulinumtoxin-A injection for disabling lower limb flexion in hemiplegic patients (1) 25 30

Rudroff, T., J.H. Kindred, P.J. Koo, R. Karki and J.R. Hebert, Asymmetric glucose uptake in leg muscles of patients with Multiple Sclerosis during walking detected by [18F]-FDG PET/CT (4) 813-823

Rymer, W.Z., see Jahanmiri-Nezhad, F. (2) 307-314

Świątek, E., see Krukowska, J. (3) 427-434

Sakalar, A., see Boyaci, A. (1) 123-129

Sakurai, H., see Koyama, S. (3) 363-368

Sale, P., see Paoloni, M. (3) 405-414

Salkovskis, P.M., see Morris, L.L. (3) 627-631

Santilli, V., see Paoloni, M. (3) 405-414

Sartor, D., see Glegg, S.M.N. (3) 563-577

Sathian, K., see Sawaki, L. (3) 415-426

Sawaki, L., A.J. Butler, X. Leng, P.A. Wassenaar, Y.M. Mohammad, S. Blanton, K. Sathian, D.S. NicholsLarsen, S.L. Wolf, D.C. Good and G.F. Wittenberg, Differential patterns of cortical reorganization following constraint-induced movement therapy during early and late period after stroke: A preliminary study (3) 415-426

Schmidt, J., see Lannin, N.A. (4) 635-641

Schneider, E., see Lannin, N.A. (4) 635-641

Seong-Youl, C., L. Jae-Shin and S. A-Young, Cognitive test to forecast unsafe driving in older drivers: Meta-analysis (4) 771-778

Sergi, G., see De Luca, R. (4) 711-717

Serpe, R., see Cugusi, L. (4) 789-794

Servello, D., see Nardo, A. (4) 779-788

Shang, A., see Lee, Y.S.C. (1) 57-65

Shears, J., see Ploughman, M. (1) 105-112

Shephard, R.J., see Leunkeu, A.N. (3) 597-606

Shephard, R.J., see Leunkeu, A.N. (4) 657-663

Shim, J.K., see Kim, Y. (3) 607-614

Shin, Y.K., D.R. Lee, D.H. Kim, J.J. Lee, S. (Joshua) Hyun You, C.H. Yi and H.S. Jeon, Effects of novel tubing gait on neuromuscular imbalance in cerebral palsy (3) 587-596

Shomoto, K., see Nakamura, J. (1) 31-37

Sienkiewicz, M., see Krukowska, J. (3) 427-434
Silveira Fernandes, A.B.G., J. Oliveira dos Passos, D. Paiva de Brito and T.F. Campos, Comparison of the immediate effect of the training with a virtual reality game in stroke patients according side brain injury (1) 39-45

Ska, B., see Zimmermann, N. (1) 159-170

Skidmore, E., see Wallace, S.E. (3) 615-625

Smith, C., see Regier, A.D. (3) 467-473

Smith, L.K. and A.M. Goberman, Long-time average spectrum in individuals with Parkinson disease (1) 77-88

Sobry, V., P. Badin, S. Cernaianu, O. Agnani and M. Toussaint, Do visually impaired people have a static balance as effective as sighted people? (4) 851-861

Solla, P., see Cugusi, L. (4) 789-794

Sorinola, I.O., I. Powis and C.M. White, Does additional exercise improve trunk function recovery in stroke patients? A meta-analysis (2) 205-213

Spielman, L., see Lu, W. (2) 245-251

Squires, S., see Ploughman, M. (1) 105-112

Srubiski, S.L., see Manson, G.A. (4) 689-700

Staniszewski, K., see Regier, A.D. (3) 467-473

Stanton, S., see Glegg, S.M.N. (3) 563-577

Stasolla, F. and C. De Pace, Assistive technology to promote leisure and constructive engagement by two boys emerged from a minimal conscious state (2) 253-259

Stepp, C.E., see Malloy, J.R. (4) 795-803

Stevens, C.A., see Malloy, J.R. (4) 795-803

Sturnieks, D.L., see McLoughlin, J.V. (3) 503-508

Suh, D.-W., see Kim, Y. (3) 607-614

Suresh, B.V., see Iyengar, Y.R. (2) 181-190

Suresh, N.L., see Jahanmiri-Nezhad, F. (2) 307-314

Suzuki, W., see Lee, Y.S.C. (1) 57-65

Tanabe, S., see Koyama, S. (3) 363-368

Tánczos, T., D. Zádori, K. Jakab, Z. Hnyilicza, P. Klivényi, L. Keresztes, J. Engelhardt, D. Németh and L. Vécsei, The role of cognitive training in the neurorehabilitation of a patient who survived a lightning strike. A case study (1) 137-146

Tavernese, E., see Paoloni, M. (3) 405-414

Tegtbur, U., see Kerling, A. (1) 97-104

Teixeira-Poit, S., see Kane, H. (1) 89-95

Teixeira-Salmela, L.F., see Lima, R.C.M. (3) 391-404

Tibæk, M., see Linnemann, M. (4) 755-761

Tong, W., see Caizhong, X. (4) 835-840

Toussaint, M., see Sobry, V. (4) 851-861

Tramonti, F., C. Fanciullacci, G. Giunti, B. Rossi and C. Chisari, Functional status and quality of life 
of stroke survivors undergoing rehabilitation programmes in a hospital setting (1) 1-7

Tremblay, L., see Manson, G.A. (4) 689-700

Turnbull, M., see Lannin, N.A. (4) 635-641

Turner, B., see Kuipers, P. (3) 475-480

Tutoglu, A., see Boyaci, A. (1) 123-129

Unnikrishnan, B., see Iyengar, Y.R. (2) 181-190

Upadhyay, N., see Munivenkatappa, A. (3) 481-484

Valentin, J.C., see Malloy, J.R. (4) 795-803

Vécsei, L., see Tánczos, T. (1) 137-146

Vela-Desojo, L., see Cano-de-la-Cuerda, R. (3) 493-501

Velikonja, D., see Glegg, S.M.N. (3) 563-577

Ventura, J.L., see Corral, L. (4) 763-769

Venturi, M., see Chisari, C. (3) 509-518

Vijayakumar, K., see Iyengar, Y.R. (2) 181-190

Vilarrasa, A.B., see Castaño Monsalve, B. (1) 67-76

Viscor, G., see Corral, L. (4) 763-769

Vroman, K.G., see Ness, B.M. (1) 147-158

Wallace, S.E., M. Purdy and E. Skidmore, A multimodal communication program for aphasia during inpatient rehabilitation: A case study (3) 615-625

Wang, Z., D. Kou, Z. Li, Y. He, W. Yu and H. Du, Effects of propofol-dexmedetomidine combination on ischemia reperfusion-induced cerebral injury (4) 825-834

Warashina, H., see Koyama, S. (3) 363-368

Wassenaar, P.A., see Sawaki, L. (3) 415-426

Wens, I., see Op 't Eijnde, B. (4) 805-811

Wermuth, L., see Morberg, B.M. (2) 291-298

White, C.M., see Sorinola, I.O. (2) 205-213

Willerslev-Olsen, M., J. Lorentzen and J.B. Nielsen, Gait training reduces ankle joint stiffness and facilitates heel strike in children with Cerebral Palsy (4) 643-655

Williams, C.K., see Manson, G.A. (4) 689-700
Williams, J.E., see Wood, R.M. (2) 171-179

Windhagen, A., see Kerling, A. (1) 97-104

Wittenberg, G.F., see Sawaki, L. (3) 415-426

Wolf, S.L., see Sawaki, L. (3) 415-426

Wood, R.M., J.D. Griffiths, J.E. Williams and J.Brouwers, Optimising resource management in neurorehabilitation (2) 171-179

Wright, J., see Lequerica, A. (3) 485-492

Yan, T., see You, G. (3) 381-389

Yarossi, M., see Pilkar, R. (2) 299-305

Yeh, S.-C., S.-H. Lee, R.-C. Chan, S. Chen and A. Rizzo, A virtual reality system integrated with robot-assisted haptics to simulate pinch-grip task: Motor ingredients for the assessment in chronic stroke (3) 435-449

Yi, C.H., see Shin, Y.K. (3) 587-596

Yoon, B.C., see Kim, Y. (3) 607-614

Yoon, T.S., see Na, E.H. (3) 459-466

You, G., H. Liang and T. Yan, Functional electrical stimulation early after stroke improves lower limb motor function and ability in activities of daily living (3) 381-389

You, S.H., see Lee, D.R. (1) 131-136

Yu, W., see Wang, Z. (4) 825-834

Yuda, T., see Nakamura, J. (1) 31-37

Zádori, D., see Tánczos, T. (1) 137-146

Zebenholzer, K., see Pusswald, G. (3) 519-527

Zedda, F., see Cugusi, L. (4) 789-794

Zhiqing, D., see Caizhong, X. (4) 835-840

Zhou, P., see Jahanmiri-Nezhad, F. (2) 307-314

Zimmermann, N., T.M. Netto, M.T. Amodeo, B. Ska and R.P. Fonseca, Working memory training and poetry-based stimulation programs: Are there differences in cognitive outcome in healthy older adults? (1) 159-170

Zory, R., see Boudarham, J. (3) 369-379 